\title{
Interaction Effect of Sex, Locality and Self-Confidence on Emotional Intelligence among Prospective Teachers
}

\author{
Dr. Prem Shankar Srivastava \\ Principal, V.B. College of Education, Deekshapuram, Sabour, Bhagalpur, \\ Bihar-813210
}

Accepted: May 06, 2012 Published: July 09, 2012

Doi:10.5296/ijld.v2i4.2076 URL: http://dx.doi.org/10.5296/ijld.v2i4.2076

\begin{abstract}
The present study has been carried out to assess the interaction effect of sex, locality and self-confidence on Emotional Intelligence on a sample of 100 prospective teachers both male and female belonging to urban and rural localities by applying a $(2 \times 2 \times 2)$ three way factorial design. The data has been collected with the help of Self - Confidence Scale (Bhawlkar, 1992) and Emotional Intelligence Scale (Kumar, 2000). It has been revealed that the main effects of sex and self - confidence are found to be significant whereas the main effects of locality as well as the various interactions are found to be non - significant.
\end{abstract}

\section{INTRODUCTION}

Self - Confidence is an important factor in enhancing Emotional Intelligence amongst individuals. The measurement of self- confidence becomes more essential. Various methods and techniques have been developed to measure self-confidence. The problem of measuring self-confidence at a large extent cut a sorry figure due to the concept of 'self' is ambiguous. Smith (1962) identified six areas of self; the first of them is self-confidence. The personality pattern is a multi dimensional structure in which the concept of self is the core or centre of gravity (Breckenridge and Vincent, 1965). Into this, there are many behaviour patterns known as traits which are closely associated with the concept of self. Self confidence is a personality trait (Agnihotri, 1987). Basavanna (1975) defined, "In general terms self - confidence refers to an individual's perceived ability to act effectively in a situation to overcome obstacles and to get things go all right." 
Agnihotri (1987) defined "The self is a composite of a person's thoughts and feelings, strivings and hopes, fears and fantasies, his view of what he is, what he has been, what he might become, and his attitude pertaining to his worth. Self-confidence is a positive attitude of one self towards one's self concept."

Kothari Commission (1964-66) pointed out that "the destiny of its nation is being shaped in her classrooms." The all round development of the children is only in the hand of teachers. Now a day people are unsatisfied with the development - taking place in four walls of classroom. The behaviour pattern of children is on the decline. There may be several reasons for such type of affairs.

Pradhan and Bano (2000) write emotions are the currents of energy that are within us. It activates our lives, shapes, our perceptions and behaviour. It simply deals with feelings such as anger, love, joy and sadness. The term 'Emotional Intelligence' was coined by Salovey and Mayer (1990) but it got popularized by Goleman (1995) with a book "Emotional Intelligence: Why it can matter more than IQ" and another book "Working With Emotional Intelligence" (1998). Emotional Intelligence is the ability to understand and express your emotions to meet the requirement of day to day living, learning and relating to others" (Cherniss, 2000).

A lot of research work has been done to find out the factors of Emotional Intelligence. Sex has been found as one of the dominant factors of Emotional Intelligence. Pandey (2000) and Pandey (2002) found Emotional Intelligence as a gender free construct. Chouhan and Bhatnagar (2003) found female students have higher degree of EQ than their counterparts. But Deo Lal (2003) found male students possess more EQ than their counterparts.

Another factor which is closely related to emotional intelligence is the locality. Kumar (2001) and Singh (2005) found boys and girls of rural area have more emotional intelligence than that of urban area. Self - Confidence is the most important factor in determining emotional intelligence. Cherniss (1998) has suggested high emotionally intelligent leaders possess higher levels of self-confidence. Agnihotri (1987) supports a self confident person perceives himself to be emotionally mature.

A survey of research evidences indicate that sex, locality and self - confidence are closely associated with student's emotional intelligence. Thus, most of the studies reported above have been conducted on school going children and others but a very limited attempt has been made to enhance emotional intelligence among teacher trainees. So that it is necessary to undertake a study for identifying the factors that are responsible for the Emotional Intelligence among prospective teachers. The present paper is an effort to find out the factors of Emotional Intelligence. Since emotional problems are felt by different sexes, different localities and different levels of self - confidence. Thus, the investigator decides to conduct a study to see the 
effect of sex, locality and self-confidence on Emotional Intelligence among Prospective Teachers.

\section{Statement of the Problem}

The Problem for the purpose of investigation may be stated as:

"Interaction Effect of Sex, Locality and Self - Confidence on Emotional Intelligence among Prospective Teachers."

\section{Operational Definitions of the Terms -}

\section{Emotional Intelligence}

It has been defined as "The ability to sense understand value and effectively apply the power and acumens of emotions as a source of human energy, information, trust, creativity and influence" (Cooper and Sawaf, 1997).

Operationally it may be defined as "The score obtained by the Prospective Teachers on Emotional Intelligence Scale developed by Kumar (2000).

\section{Self - Confidence}

It is faith in one's own ability which enables the individual to be dependable, to rely upon his own judgment, not to be submissive and to feel himself adequate to do things he wants to do (Bhawalkar, 1992).

Self- confidence may be defined operationally as, "The score obtained by the Prospective Teachers on Self - Confidence Scale developed by Bhawlkar (1992).

\section{Delimitation of the Study}

Keeping in view the limitation of time, resources and energy, the investigation has been delimited both qualitatively and quantitatively as under:

Only 100 Prospective Teachers both sexes - male and female belonging to urban and rural localities of Bhagalpur District have been considered for the study.

\section{Objective of the Study}

To study the effect of sex, locality and self-confidence and their various interactions on the Emotional Intelligence among Prospective Teachers.

\section{Basic Assumption}

i) The Emotional Intelligence Scale can measure the Emotional Intelligence of Prospective Teachers. 
ii) The Self-Confidence Scale can give information regarding self-confidence of Prospective Teachers.

\section{Hypothesis}

To achieve the above mentioned objective, the following hypothesis has been formulated in the present study:

There would be significant effect of sex, locality, self-confidence and their various interactions on the Emotional Intelligence among prospective teachers.

\section{METHODOLOGY:}

\section{Sample}

The sample of the present study consists of 100 male and female prospective teachers who have been selected randomly belonging to urban and rural localities of Bhagalpur District (Bihar).

TABLE - 1

Detail of the Sample

\begin{tabular}{|c|c|c|c|c|c|}
\hline \multirow{2}{*}{$\begin{array}{c}\text { Sex / Self Confidence / } \\
\text { Locality }\end{array}$} & \multicolumn{2}{|c|}{$\mathrm{A}_{1}$} & \multicolumn{2}{|c|}{$\mathrm{A}_{2}$} & \multirow{2}{*}{ Total } \\
\cline { 2 - 5 } & $\mathrm{C}_{1}$ & $\mathrm{C}_{2}$ & $\mathrm{C}_{1}$ & $\mathrm{C}_{2}$ & \\
\hline $\mathrm{B}_{1}$ & 15 & 10 & 12 & 16 & 53 \\
\hline $\mathrm{B}_{2}$ & 13 & 9 & 11 & 14 & 47 \\
\hline Total & 28 & 19 & 23 & 30 & 100 \\
\hline
\end{tabular}
$\mathrm{A}_{1}=$ Male
$\mathrm{A}_{2}=$ Female
$\mathrm{B}_{1}=$ Urban
$\mathrm{B}_{2}=$ Rural
$\mathrm{C}_{1}=$ High Self - Confident
$\mathrm{C}_{2}=$ Low Self - Confident

\section{Psychometric Instruments}

i- $\quad$ Emotional Intelligence Scale developed by Kumar (2000) has been used in the present study to measure Emotional Intelligence of Prospective Teachers.

ii- $\quad$ Self - Confidence Scale developed by Bhawlkar (1992) has been selected for the study to assess self - confidence of the Prospective Teachers.

\section{Procedure}

The tests have been administered and scored as direction given in the manuals. 


\section{Data Organization}

Median has been calculated from the scores of self - confidence and on that basis the sample has been divided into two sub groups. The Calculated median value for self - confidence is 49 , hence, scores 49 and above have been placed in the group of high self - confident and the scores 48 and below have been treated as the group of low self - confident.

\section{Statistical Techniques}

The independent variables are sex locality and self - confidence and the dependent variable is emotional intelligence. Each of the independent variables has been differed in two ways. Hence a Factorial Analysis of Variance $(2 \times 2 \times 2)$ has been used to analyze the independent and interactive effects of independent variables on the dependent variable. The present study investigates the interactions among different levels of sex, locality and self- confidence which involved the comparison of more than two means.

If ANOVA yields significant ' $F$ ' Ratio, the ' $t$ ' test has been used in order to test the significance of the difference between the means of the two groups.

\section{ANALYSIS OF DATA}

TABLE - 2

\section{CELL (MEANS AND SDs)}

\begin{tabular}{|c|c|c|c|c|}
\hline \multirow{2}{*}{} & \multicolumn{2}{|c|}{$\mathrm{A}_{1}$ (Male) } & \multicolumn{2}{c|}{$\mathrm{A}_{2}$ (Female) } \\
\cline { 2 - 5 } & $\mathrm{C}_{1}$ & $\mathrm{C}_{2}$ & $\mathrm{C}_{1}$ & $\mathrm{C}_{2}$ \\
\hline $\mathrm{B}_{1}$ & $15(169.6,31.62)$ & $10(166.9,28.65)$ & $12(176.75,30.11)$ & $16(135.81,35.26)$ \\
\hline $\mathrm{B}_{2}$ & $13(169.0,19.37)$ & $9(136.0,28.99)$ & $11(161.0,21.46)$ & $14(132.5,26.85)$ \\
\hline Total & $28(169.3,25.5)$ & $19(151.45,28.82)$ & $23(168.86,25.79)$ & $30(134.16,31.56)$ \\
\hline
\end{tabular}

\section{TABLE - 3}

Summary of ANOVA $(2 \times 2 \times 2)$ of Sex, Locality and Self-Confidence on Emotional Intelligence

\begin{tabular}{|c|c|c|c|c|c|c|}
\hline & Source of Variation & $\begin{array}{c}\text { Sum of } \\
\text { Square }\end{array}$ & df & $\begin{array}{c}\text { Mean } \\
\text { Square }\end{array}$ & F-Ratio & $\begin{array}{c}\text { Level of } \\
\text { Significant }\end{array}$ \\
\hline A & SEX & 4204.24 & 1 & 4204.24 & 4.68 & 0.05 \\
\hline B & LOCALITY & 2784.64 & 1 & 2784.64 & 3.097 & NS \\
\hline C & SELF-CONFIDENCE & 19633.60 & 1 & 19633.60 & 21.84 & 0.01 \\
\hline AXB & SEX x LOCALITY & 112.82 & 1 & 112.82 & 0.125 & NS \\
\hline
\end{tabular}




\begin{tabular}{|c|c|c|c|c|c|c|}
\hline BXC & $\begin{array}{c}\text { LOCALITY } x \\
\text { SELF-CONFIDENCE }\end{array}$ & 227.20 & 1 & 277.20 & 0.308 & NS \\
\hline AXC & $\begin{array}{c}\text { SEX x } \\
\text { SELF-CONFIDENCE }\end{array}$ & -436.64 & 1 & -436.64 & -0.486 & NS \\
\hline AxBxC & $\begin{array}{c}\text { SEX x LOCALITY x } \\
\text { SELF-CONFIDENCE }\end{array}$ & 2856.18 & 1 & 2856.18 & 3.18 & NS \\
\hline & Between Treatment & 29432.04 & 7 & 4204.58 & & \\
\hline & Within Treatment & 82704.80 & 92 & 898.97 & & \\
\hline & Total & 112136.84 & 99 & & & \\
\hline
\end{tabular}

From the above analysis, the main effects of sex and self - confidence have been found to be significant at .05 and .01 levels of significance, respectively, while the main effects of locality as well as the various interactions have been found to be non-significant. In order to test the levels of self-confidence at which the significant difference occurs, the ' $t$ ' test has been used.

TABLE -4

' $t$ ' - Ratio for the Different Levels of Self - Confidence

\begin{tabular}{|c|c|c|c|c|c|c|}
\hline $\begin{array}{c}\text { Levels of Self- } \\
\text { Confidence }\end{array}$ & N & Mean & S.D. & S.Ed & t Value & $\begin{array}{c}\text { Level of } \\
\text { Significant }\end{array}$ \\
\cline { 1 - 5 } High & 51 & 58.98 & 5.76 & \multirow{2}{*}{1.1230} & 3.87 & 0.01 \\
\hline Low & 49 & 54.63 & 5.47 & & \\
\hline
\end{tabular}

The above table points out that high level self-confidence group differs significantly with low level self- confidence group whereas the difference between high and low self - confidence groups are found significant.

TABLE - 5

Mean E I Scores of the Different Levels of Self - Confidence

\begin{tabular}{|c|c|c|c|c|c|c|}
\hline $\begin{array}{c}\text { Levels of Self- } \\
\text { Confidence }\end{array}$ & $\mathrm{N}$ & Mean & S.D. & S.Ed & t Value & $\begin{array}{c}\text { Level of } \\
\text { Significant }\end{array}$ \\
\cline { 1 - 5 } High & 51 & 169.08 & 25.65 & \multirow{2}{*}{5.613} & 4.68 & 0.01 \\
\hline Low & 49 & 142.81 & 30.19 & & \\
\hline
\end{tabular}

From the above Table 5, it is clear that the prospective teachers having high self-confidence show greater emotional intelligence in comparison to low level self-confidence. 


\section{1) Macrothink}

DISCUSSION

From the analysis of the data presented in the above mentioned tables, it is revealed that the hypothesis "There would be significant effect of Sex, Locality, Self - Confidence and their various interactions on the "Emotional Intelligence" is partially accepted and partially rejected. From Table - 3, it is clear that the hypothesis "There would be significant effect of sex, locality and self-confidence on the Emotional Intelligence among prospective teachers." is accepted in case of the main effect of sex on emotional intelligence. This finding does not find support from the findings of Pandey (2000) and Pandey (2002). It finds support from the findings of Deolal (2000). The hypothesis is also accepted in case of the main effect of self - confidence on EI supporting the findings of Cherniss (1998) and Agnihotri (1987). Thus the hypothesis is accepted in case of the main effects of sex and self - confidence and is rejected in case of the main effect of locality as well as the first and second order interactions AXB, BXC, AXC and AXBXC. This means that locality, sex and locality, locality and self-confidence, sex and self -confidence, and sex, locality and self-confidence have no significant effect on Emotional Intelligence among prospective teachers.

\section{CONCLUSION}

On the basis of above findings, it is concluded that the main effects of sex and self - confidence on EI are found to be significant whereas the main effect of locality as well as the various combined interactions of sex and locality, locality and self - confidence, sex and self -confidence and triple interaction of sex, locality and self - confidence on Emotional Intelligence are found to be non - significant.

\section{REFERENCES}

Agnihotri, R. (1987): “Manual for Agnihotri’s Self - Confidence Inventory.” NPC Agra.

Bhawalkar (1992):

"Verbal Measure of Self - Confidence."

Basavanna, M. (1975):

"Manual of Self - Confidence Inventory" RPC Varanasi

Breekenridge, E.M. and 
Vincent, E.L. (1965):

2012, Vol. 2, No. 4

Chouhan, V.L. and

Bhatnagar, T. (2003):

“Child Development" Philadelphia, Saunders.

"Assessing Emotional Maturity, Emotional Expression and Emotional Quotient of Adolescent Male and Female students" Journal of Community Guidance and Research, Volume 20 (2) 157-167.

Cooper, R.K. and Sawaf, A (1997) : "Executive EQ: Emotional intelligence in Lander ship and organizations". Orion business books Pvt.

Cherniss, C. and Adler M (2000): "Promoting Emotional Intelligence in Organization" Virginia ASTD

Deolal, G.N. (2003):

"A study of EI and GI Ability of Kumaun Adolescents in relation to their academic achievement and academic stream" PhD K.U. Nainital.

Goleman, D. (1995): "Emotional Intelligence Issue in Paradigm." Edited by C. Cherniss and Daniel Goleman from the book the Emotionally Intelligence Workplace. Amazon.com.

Goleman, D. (1995): "Emotional Intelligence: Why It Can Matter More Than IQ?" New York: Bantam Books.

Goleman, D. (1998):

"Working with Emotional Intelligence." New York, Bantam Books.

Kothari, D.S. (1964-66): "National Education Commission." Govt. of India, New Delhi.

Kumar, G. (2000): "Emotional Intelligence Scale.” M.J.P.R.University, Bareilly.

Kumar, D. (2007): "Study of EI of Primary School Teachers in relation to their gender, age, caste, teaching experience and school." Ph.D Ed. K.U. Nainital.

Pradhan, R.K. and

Bano, S. (2000):

Pandey, M.K. (2000):

"The Credo of Emotional Intelligence" Employment News, Oct. New Delhi.

"Study of EI of adolescent students in relation to their achievement in Maths, academic stream and gender." Ph.D. Edu. K.U. Nainital.

Pandey, T.C. (2002): "A study of EI and attitude towards Modernization of Kumauni adolescents in relation to some socio-families and educational factors." Ph.D. K.U. Nainital.

Salovey, P. and Mayer, J.D. (1990): "Emotional Intelligence: Imagination Cognition and Personality." 9, 185-211. 


\section{Macrothink

Smith, P.A. (1962):

"A comparison of three sets of related facts or analytic solutions for self-concept data." Journal of Abnormal and Social Psychology, 64, 326-333.

Singh, D. (2001):

"Emotional Intelligence at Work. A Professional Guide." Response Book, A division of Sage Publication, New Delhi. 